\title{
Amphetamine and Dopamine-Induced Immediate Early Gene Expression in Striatal Neurons Depends on Postsynaptic NMDA Receptors and Calcium
}

\author{
Christine Konradi, Jean-Christophe Leveque, and Steven E. Hyman \\ Molecular and Developmental Neuroscience Laboratory and Department of Psychiatry, Massachusetts General Hospital \\ and Harvard Medical School, Boston, Massachusetts 02114
}

Amphetamine and cocaine induce the expression of both immediate early genes (IEGs) and neuropeptide genes in rat striatum. Despite the demonstrated dependence of these effects on $D_{1}$ dopamine receptors, which activate the cyclic AMP pathway, there are several reports that amphetamine and cocaine-induced IEG expression can be inhibited in striatum in vivo by NMDA receptor antagonists. We find that in vivo, the NMDA receptor antagonist MK-801 inhibits amphetamine induction of $c$-fos acutely and also prevents downregulation of IEG expression with chronic amphetamine administration. Such observations raise the question of whether dopamine/glutamate interactions occur at the level of corticostriatal and mesostriatal circuitry or within striatal neurons. Therefore, we studied dissociated striatal cultures in which midbrain and cortical presynaptic inputs are removed. In these cultures, we find that dopamine- or forskolin-mediated IEG induction requires $\mathrm{Ca}^{2+}$ entry via NMDA receptors but not via L-type $\mathrm{Ca}^{2+}$ channels. Moreover, blockade of NMDA receptors diminishes the ability of dopamine to induce phosphorylation of the cyclic AMP responsive element binding protein $\mathrm{CREB}$. Although these results do not rule out a role for circuit-level dopamine/glutamate interactions, they demonstrate a requirement at the cellular level for interactions between the cyclic AMP and NMDA receptor pathways in dopamine-regulated gene expression in striatal neurons.

Key words: dopamine; amphetamine; NMDA; striatum; immediate early genes; Fos; CREB
Amphetamine is a psychostimulant drug of abuse that produces long-term changes in behavior including sensitization, tolerance, and dependence (Klawans et al., 1978; Segal et al., 1980; Robinson and Becker, 1986). Although it is well established that amphetamine is an indirect dopamine agonist (Moore, 1977; McMillan, 1983; Butcher et al., 1988), the biological mechanisms by which dopamine receptor stimulation produces prolonged behavioral changes remain unknown. Based on the extended time course of drug-induced alterations in behavior, amphetamineinduced regulation of striatal gene expression, including immediate early genes (IEGs), has been sought and documented (Graybiel et al., 1990; Moratalla et al., 1992; Nguyen et al., 1992; Konradi et al., 1994; Cole et al., 1995). Several IEGs regulated by amphetamine encode nuclear proteins that can, in turn, activate or repress the expression of other genes. Thus, IEGs are potential candidates for involvement in long-term alterations in neural function that may affect behavior.

$\mathrm{D}_{1}$ dopamine receptors have been shown to be required for the dopamine-dependent activation of IEG expression both in intact rat striatum in vivo and in dissociated primary striatal cultures (Graybiel et al., 1990; Moratalla et al., 1992; Nguyen et al., 1992; Konradi et al., 1994; Cole et al., 1995). $\mathrm{D}_{1}$ dopamine receptors are positively coupled to adenylyl cyclase (Kebabian and Calne, 1979;

Received Jan. 22, 1996; revised April 9, 1996; accepted April 11, 1996.

This work was supported by Public Health Service Grants DA07134 and DA00257.

Correspondence should be addressed to Dr. Konradi, Laboratory of Molecular and Developmental Neuroscience, Massachusetts General Hospital, CNY 2, 149, 13th Street, Charlestown, MA 02129.

Dr. Hyman's current address: Office of the Director, National Institute of Mental Health, 5600 Fishers Lane, Rockville, MD 20857.

Copyright (C) 1996 Society for Neuroscience $0270-6474 / 96 / 164231-09 \$ 05.00 / 0$
Monsma et al., 1990), thus activating the cyclic AMP pathway. One major nuclear target of the cAMP pathway is a transcription factor, the cyclic AMP responsive element binding (CREB) protein, which binds cyclic AMP response elements (CREs) and activates transcription when phosphorylated on its $\operatorname{Ser}^{133}$ (Montminy and Bilezikjian, 1987; Gonzalez and Montminy, 1989). The promoter of the IEG $c$-fos contains several CREs (Sassone-Corsi et al., 1988b). We have shown previously that the $c$-fos gene is induced by amphetamine in striatum in a CREB-dependent manner (Konradi et al., 1994).

In addition to the cyclic AMP-dependent protein kinase, calcium/calmodulin-dependent protein kinases can phosphorylate CREB on Ser $^{133}$ as well as on other serines (Dash et al., 1991; Sheng et al., 1991; Sun et al., 1994). Nonetheless, activation of the cyclic AMP pathway has been shown to be necessary and sufficient for induction of CREB-regulated genes in several transformed cell lines (Nguyen et al., 1990). Thus, it is somewhat puzzling that amphetamine-mediated induction of $c$-fos and zif 268 gene expression has been reported to be inhibited by NMDA receptor antagonists in vivo (Snyder-Keller, 1991; Ohno et al., 1994; Wang et al., 1994). Hypotheses that have been adduced to explain these observations generally have focused on neural circuitry: NMDAreceptor blockade has been hypothesized to inhibit the release of dopamine and, perhaps, serotonin within the striatum or to inhibit dopamine $\mathrm{D}_{1}$ receptor function (Kashihara et al., 1990; Johnson and Jeng, 1991; Krebs et al., 1991; Wang, 1991). Moreover, marked differences might exist between the regulation of intracellular signaling pathways in the transformed cell lines studied previously versus striatal neurons; for example, the mode of $\mathrm{Ca}^{2+}$ entry, including its cellular localization, might influence its interactions with the cAMP pathway in regulating gene expression. 


\begin{tabular}{|c|c|c|c|c|c|}
\hline \multirow{2}{*}{$\frac{\text { Day of treatment }}{\text { Group }}$} & \multicolumn{2}{|c|}{ Days $1-11$} & \multicolumn{2}{|l|}{ Day 12} & \\
\hline & Initial & 15 min later & Initial & 15 min later & \\
\hline 2 & Saline & Saline & Saline & Amph* & Acute amph \\
\hline 3 & MK-801 & Saline & MK-801 & Saline & Chronic MK-801 \\
\hline 4 & Saline & Amph & Saline & Amph & Chronic amph \\
\hline 6 & MK-801 & Amph & Saline & Amph & Chronic amph blocked by MK-801, unblocked at last injection \\
\hline
\end{tabular}

*Amph, S(+)-amphetamine sulfate. Drug concentrations: amph, 4 mg/kg; MK-801, $1 \mathrm{mg} / \mathrm{kg}$.

Because a number of potential substrates exist for dopamine/ glutamate interactions within the circuitry controlling striatal inputs, we studied both whole animal preparations and also dissociated embryonic day 18 (E18) neuron-enriched primary striatal cultures in which the confounding variables introduced by circuitry would be eliminated. To ensure that our results were not biased by peculiarities of the regulation of particular IEGs, (e.g., $c$-fos autoregulation) (Sassone-Corsi et al., 1988a), the regulation of multiple IEGs was studied.

\section{MATERIALS AND METHODS}

Drugs and drug paradigms. Dopamine, the dopamine $\mathrm{D}_{1}$ receptor agonists SKF-38393 and SKF-82958, the NMDA receptor antagonists D(-)-2amino-5-phosphonopentanoic acid (APV) and (+)-MK-801 hydrogen maleate (MK-801), the L-type $\mathrm{Ca}^{2+}$ channel blockers nifedipine and verapamil, and amphetamine were obtained from RBI (Natick, MA). EGTA was obtained from Sigma (St. Louis, MO). Fos antibody for immunocytochemistry was obtained from Oncogene Science (Ab-2) (Uniondale, NY), and immunocytochemistry was performed as described (Konradi et al., 1994).

$\mathrm{S}(+)$-amphetamine sulfate equivalent to $4 \mathrm{mg} / \mathrm{kg}$ free base was administered in the rat experiments intraperitoneally. MK- 801 hydrogen maleate equivalent to 0.5 to $1 \mathrm{mg} / \mathrm{kg}$ free base also was administered intraperitoneally. For acute rat experiments, amphetamine was administered $30 \mathrm{~min}$ before killing. When used, MK-801 pretreatment was given 15 min before amphetamine. Chronic experiments were carried out for $12 \mathrm{~d}$, with single daily injections of drugs. For details, see Table 1.

For experiments in E18 primary striatal cultures, drugs were added 30 min before harvest. When used, MK-801 pretreatment was given $30 \mathrm{~min}$ to $1 \mathrm{hr}$ before other drugs. For experiments in $\mathrm{Ca}^{2+}$-free media, cells were washed and then fed with these media 6 or $18 \mathrm{hr}$ before drug stimulation.

MK-801 binding. Analysis of $\left[{ }^{3} \mathrm{H}\right] \mathrm{MK}-801$ binding was performed as described previously (Kornhuber et al., 1989). Equilibrium was reached in the presence of glutamate and glycine within $4 \mathrm{hr}$. Ligand-receptor association was carried out for 4 or $18 \mathrm{hr}$ at room temperature in the presence of $5 \mu \mathrm{M}$ L-glutamic acid, $5 \mu \mathrm{M}$ glycine, and $10 \mu \mathrm{M} \mathrm{MgCl}_{2}$, in Tris/HCl buffer, $\mathrm{pH}$ 7.4. Nonspecific binding was determined in the presence of $100 \mu \mathrm{M}$ unlabeled MK-801. Total protein concentration per sample was $0.08 \mathrm{mg}$ to $0.1 \mathrm{mg}$ (method of Bradford, 1976), and total sample volume was $250 \mu$ l. Concentrations of $\left[{ }^{3} \mathrm{H}\right] \mathrm{MK}-801$ ranged from 0.3 to $40 \mathrm{~nm}$ for "hot saturation" or $1 \mathrm{~nm}\left[{ }^{3} \mathrm{H}\right] \mathrm{MK}-801$ and 0.6 to $78 \mathrm{~nm}$ unlabeled MK-801 for "cold saturation" studies. The ligand program (Munson and Rodbard, 1980) was used for data analysis. Linear Scatchard plots were obtained for "hot saturation" experiments with extracts from rat striatum, rat cortex, and rat hippocampus, thus fitting a single site model.

Animals. Male Sprague-Dawley rats (200-250 gm) were used for all experiments. They were housed four to a cage on a 12/12 hr light/dark cycle. All injections were intraperitoneal. Animals were killed by rapid decapitation for the preparation of RNA. All experiments were performed in at least six rats.

Primary striatal culture. Striata were dissected out under a stereomicroscope from 18-d-old Sprague-Dawley rat fetuses. Tissue was suspended in $2 \mathrm{ml}$ of medium (DMEM/F12, Gibco, Gaithersburg, MD) with the following supplements per liter of medium: $4.5 \mathrm{gm}$ of glucose, $10 \mathrm{ml}$ of penicillin/streptomycin liquid (Gibco), 10\% Nu-serum 1 (Collaborative
Biomedical Products, Bedford, MA), $\mathrm{Na}^{+}$bicarbonate to $\mathrm{pH}$ 7.6, with $0.2 \%$ DNase. The tissue was dissociated mechanically with a firenarrowed Pasteur pipette, and the cells resuspended in medium without DNase to $10^{6}$ cells $/ \mathrm{ml}$ and plated in six-well plates (Costar, Cambridge, MA) at $2 \times 10^{6}$ cells/well. Plates were pretreated with $2 \mathrm{ml}$ of a 1:500 diluted solution of polyethylenimine (Sigma) in $50 \mathrm{~mm}$ sodium borate buffer, $\mathrm{pH} 7.4$, for $24 \mathrm{hr}$, washed twice with PBS, left with medium for about $4 \mathrm{hr}$, and aspirated just before plating. After $18 \mathrm{hr}$, cells were placed on defined medium to prevent glial growth [DMEM/F12 with $1 \times$ B27 supplement, $0.5 \mathrm{gm}$ of glucose $/ 100 \mathrm{ml}, 1 \mathrm{ml}$ of penicillin-streptomycin liquid/100 $\mathrm{ml}$ (Gibco), and $\mathrm{Na}^{+}$bicarbonate to $\mathrm{pH}$ 7.6]. All experiments were performed in duplicate with cells $6-8 \mathrm{~d}$ in culture and repeated at least once in an independent dissection. As determined by HPLC analysis, glutamate levels in the medium on the day of the experiments ranged from 1 to $5 \mu \mathrm{M}$. Neuron-to-astroglia ratio was below 25:1, as established by immunocytochemical staining with glial fibrillary acid protein (Dako, Carpenteria, CA), and counterstained with $1 \%$ cresyl violet. For a subset of experiments, which are indicated, DMEM was substituted for DMEM/F12. DMEM medium without $\mathrm{CaCl}_{2}$ was purchased from Gibco. Drug treatments were compared in all media used to ensure that none of the media unexpectedly affected gene expression or drug activity.

Northern blot analysis of rat brain striata. Total striatal RNA $(7-10 \mu \mathrm{g})$ was prepared as described (Berger and Chirgwin, 1989) and size separated on $1.2 \%$ denaturing agarose gel (see below). All samples were electroblotted onto GeneScreen (DuPont), UV autocross-linked (Stratalinker, Stratagene, La Jolla, CA), baked in a vacuum oven at $80^{\circ} \mathrm{C}$ for 2 $\mathrm{hr}$, and hybridized with ${ }^{32} \mathrm{P}$-labeled DNA probes (cyclophilin, $c-j u n$, and zif 268; random oligonucleotide method using nonamers) (Feinberg and Vogelstein, 1983) or ${ }^{32} \mathrm{P}$-labeled RNA probes ( $c$-fos and jun-B; Gemini system, Promega, Madison, WI). Cyclophilin mRNA was used as an unregulated internal reference probe to control for loading differences (Danielson et al., 1988). A phosphorimager (Molecular Dynamics, Sunnyvale, CA) was used for data analysis.

Northern blot analysis of primary striatal cultures. Striatal cultures were lysed in $500 \mu \mathrm{l}$ of lysis buffer ( $50 \mathrm{~mm}$ Tris, $\mathrm{pH} 8.0,100 \mathrm{~mm} \mathrm{NaCl}, 5 \mathrm{~mm}$ $\left.\mathrm{MgCl}_{2}, 0.5 \% \mathrm{NP} 40\right)$. After 5 min incubation on ice, cells were scraped into microcentrifuge tubes and centrifuged for $2 \mathrm{~min}$ at 14,000 rpm and $4^{\circ} \mathrm{C}$, and the supernatant transferred and SDS added to a $0.2 \%$ final concentration. Cells were extracted twice with phenol/chloroform, followed by a chloroform extraction and ethanol precipitation. Equal amounts of RNA $(2 \mu \mathrm{g})$ were resuspended in sample buffer $(1 \mathrm{M}$ paraformaldehyde and 50\% formamide in MOPS buffer) and size separated on $1.2 \%$ denaturing agarose gel $(1 \mathrm{M}$ paraformaldehyde $)$ in MOPS buffer (20 mm MOPS, pH 7.0, $5 \mathrm{~mm}$ sodium acetate, $1 \mathrm{~mm}$ EDTA).

Electrophoretic mobility shift assay. Medium was aspirated and plates frozen on liquid nitrogen. On the day of the experiment, cells were scraped in $200 \mu \mathrm{l}$ of sonication buffer [ $20 \mathrm{~mm}$ Hepes, $25 \%$ glycerol, $0.5 \mathrm{M}$ $\mathrm{KCl}, 1.5 \mathrm{~mm} \mathrm{MgCl}_{2}, 0.4 \mathrm{~mm}$ EDTA, $5 \mathrm{~mm}$ DTT, 1 mм EGTA, $0.5 \mathrm{~mm}$ PMSF, $1 \mathrm{~mm} \mathrm{NaF}$, and $5 \mu \mathrm{M}$ microcystin (Calbiochem, San Diego, CA)] and sonicated for $5 \mathrm{sec}$. After centrifuging for $10 \mathrm{~min}$ at $14,000 \times g$ and $4^{\circ} \mathrm{C}$, the pellet was discarded and the supernatant used for electrophoretic mobility-shift assays.

For binding, $4 \mu \mathrm{l}$ of lysate was incubated on ice for $10 \mathrm{~min}$ in binding buffer (15 $\mu \mathrm{l}$ total volume) containing $10 \mathrm{~mm}$ Hepes, $\mathrm{pH} 7.9,10 \%$ glycerol, $0.1 \mathrm{~mm}$ EDTA, $8 \mathrm{~mm} \mathrm{MgCl}_{2}, 2 \mathrm{~mm}$ DTT, $10 \mathrm{mg} / \mathrm{ml}$ poly (dI-dC) at $4^{\circ} \mathrm{C}$ with or without CREB or phosphoCREB antiserum (UBI, Lake Placid, NY). The phosphoCREB antiserum recognizes CREB phosphorylated on $\operatorname{Ser}^{133}$ (Ginty et al., 1993) and was used at a concentration of 


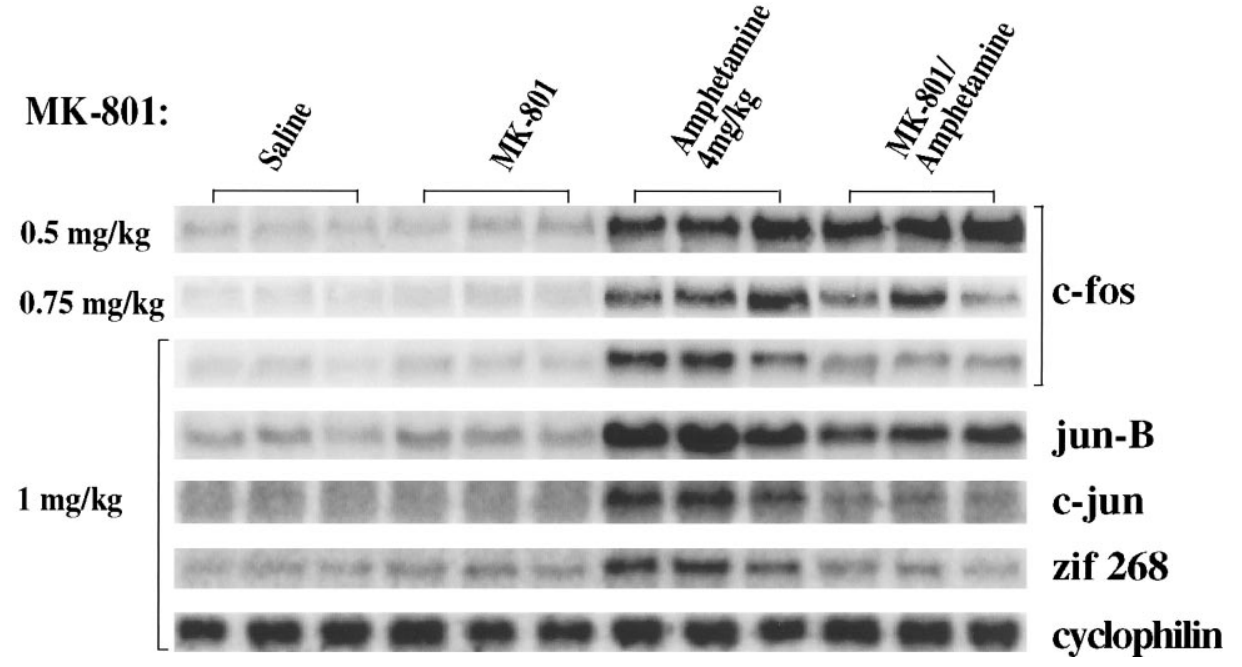

Figure 1. The NMDA antagonist MK-801 blocks amphetamine-induced IEG induction in vivo. Northern blots of rat striatal RNA probed with $c$-fos, jun-B, $c$-jun, and zif 268. Rats received two intraperitoneal injections $15 \mathrm{~min}$ apart and were killed 30 min after the second injection. Three separate experiments are shown for each condition. The conditions were as follows: Saline, two injections of saline; $M K$ 801, MK-801 at the doses shown on the left followed by saline; Amphetamine, saline followed by amphetamine (4 mg/kg); $M K-801 / A m$ phetamine, MK-801 at the doses shown on the left followed by amphetamine $(4 \mathrm{mg} / \mathrm{kg})$. A significant inhibition of IEG induction can be seen with MK-801 $(1 \mathrm{mg} / \mathrm{kg})$. Cyclophilin was used as internal loading control. Each lane is derived from a different rat; $n=9$; results were highly replicable across animals; three individual experiments shown.
$0.25 \mu \mathrm{l} /$ lane. In the presence of antiserum, preincubation was extended to $15 \mathrm{~min}$. After preincubation, $1 \mathrm{ng}$ of ${ }^{32} \mathrm{P}$-labeled double-stranded oligonucleotide was added. Samples were incubated for $10 \mathrm{~min}$ at $23^{\circ} \mathrm{C}$ and then electrophoresed through a $4 \%$ nondenaturing polyacrylamide gel (30:1 acrylamide-bisacrylamide) in $0.25 \times \mathrm{TBE}(1 \times \mathrm{TBE}$ contains $89 \mathrm{mM}$ Tris/89 mm boric acid/2.5 mm EDTA, pH 8.0) (Sambrook et al., 1989) and $3 \%$ glycerol. The gel subsequently was dried and autoradiographed.

The ATF and calcium and cyclic AMP response element (CaRE) oligonucleotides were synthesized with partial Bam $\mathrm{HI}$ sites and annealed in the presence of $20 \mathrm{mM} \mathrm{NaPO}_{4}, 1 \mathrm{~mm}$ EDTA, and $100 \mathrm{~mm} \mathrm{KCl}$. The partial BamHI sites of the double-stranded oligonucleotides then were filled in with ${ }^{32} \mathrm{P}$-labeled dCTP and unlabeled dATP, dGTP, and dTTP. Sequence of oligonucleotides used in electrophoretic mobility shift assays were: ATF: 5' GATCGCTGACGTCAGGG 3' (Hoeffler et al., 1988) and c-fos CaRE site: 5'GATCCCCGTGACGTTTACA 3' (Sheng et al., 1990). The partial Bam HI site is shown in italic, core consensus sequences are in bold.

Cyclic AMP levels were determined with the cyclic AMP $\left[{ }^{3} \mathrm{H}\right]$ assay system from Amersham (Arlington Heights, IL). Levels of cyclic AMP were determined per well of six-well tissue culture plates $\left(\sim 2 \times 10^{6}\right.$ cells $)$. Experiments were performed in duplicate and repeated at least three times per treatment condition.

\section{RESULTS}

\section{MK-801 inhibits acute amphetamine-induced IEG expression and chronic amphetamine-induced downregulation of IEG expression in rat striatum in vivo}

The effects of increasing concentrations of MK-801 on amphetamine-induced $(4 \mathrm{mg} / \mathrm{kg}$ ) IEG expression in rat striatum were examined by Northern analysis. When MK-801 $(0.5 \mathrm{mg} / \mathrm{kg})$ was given $15 \mathrm{~min}$ before amphetamine $(4 \mathrm{mg} / \mathrm{kg})$, there was a minimal block of amphetamine-induced $c$-fos mRNA (Fig. 1) and of jun-B, $c$-jun, and zif 268 mRNAs (data not shown). Inhibition was apparent with MK-801 pretreatment $(0.75 \mathrm{mg} / \mathrm{kg})$. With MK$801(1.0 \mathrm{mg} / \mathrm{kg})$, amphetamine-induced IEG expression was reduced by more than $50 \%$ for each of the IEGs studied: induction of $c$-fos mRNA was reduced from eightfold to twofold; jun-B mRNA induction was reduced from sixfold to threefold; $c$-jun mRNA induction was reduced from fourfold to 1.5 -fold; and zif 268 induction was reduced from 2.5-fold to no induction (Fig. 1, bottom five panels; all data normalized to cyclophilin, bottom panel). These data thus support previous findings demonstrating an inhibition of dopamine receptor-mediated IEG expression by MK-801 (Snyder-Keller, 1991; Torres and Rivier, 1993; Ohno et al., 1994; Wang et al., 1994). MK-801 (1 mg/kg) independently induced Fos immunocytochemical staining in cortical areas, but not in the striatum (data not shown) (see also Dragunow and Faull, 1990). MK-801-mediated induction of cortical Fos (Dragunow and Faull, 1990) may be mediated by inhibition of GABAergic interneurons, thus disinhibiting neurons regulated by GABA (Olney et al., 1989).

Repeated treatment with amphetamine or cocaine has been shown to downregulate the inducibility of multiple IEGs (Hope et al., 1992), potentially representing a component of amphetamine tolerance. With chronic amphetamine administration $(4 \mathrm{mg} / \mathrm{kg}$, i.p., for $12 \mathrm{~d}$ ) (see Table 1 for treatment paradigms), we observed downregulation of IEG induction as expected (Fig. 2, compare lanes 2 and 4; similar results for c-jun and zif 268 not shown). Because MK-801 inhibited acute induction of IEGs (Fig. 1), we hypothesized that it also might block downregulation of IEG induction. Rats, therefore, were pretreated with MK-801 (1 mg/ $\mathrm{kg}$ ) before each injection of amphetamine $(4 \mathrm{mg} / \mathrm{kg})$ for $11 \mathrm{~d}$. On day 12, the MK-801 pretreatment was omitted (and replaced with saline). Rats treated in this manner demonstrated $50 \%$ greater amphetamine-induced IEG mRNA than rats treated with a single acute dose of amphetamine (Fig. 2, compare lanes 2 and 6) and did not exhibit chronic amphetamine-induced downregulation of IEG induction (Fig. 2, compare lanes 4 and 6).

\section{MK-801 acts at a single binding site in the rat strain used}

MK-801, which is a noncompetitive NMDA antagonist (Wong et al., 1986), has been reported to interact with sites other than the NMDA receptor channel. In particular, MK-801 has two binding sites in human brain frontal cortex (Kornhuber et al., 1989), one of which may be the nicotinic acetylcholine receptor (Kavanaugh et al., 1989; Kornhuber et al., 1989; Amador and Dani, 1991). Because there has been conflicting evidence about the number of binding sites in rodent brain (Wong et al., 1988; Javitt and Zukin, 1989), we performed $\left[{ }^{3} \mathrm{H}\right] \mathrm{MK}-801$ binding analyses of multiple rat brain areas (Table 2) to investigate the specificity of MK-801 binding in our rat strain. With increasing concentrations of $\left[{ }^{3} \mathrm{H}\right] \mathrm{MK}-801$ in the binding assay ("hot saturation"), all areas examined yielded linear Scatchard analyses (Fig. 3; Table 2), which are consistent with a single MK-801 binding site. With a different binding method ("cold saturation") using increasing concentrations of unlabeled MK-801 to displace a single concentration of $\left[{ }^{3} \mathrm{H}\right] \mathrm{MK}-801$, the binding data failed to fit a linear plot (data not shown), but also were not consistent with multiple 


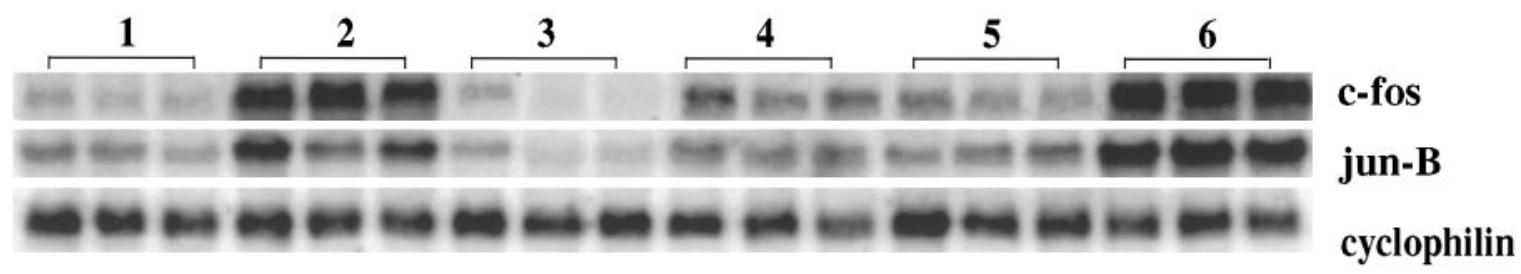

Figure 2. Chronic amphetamine-induced downregulation of IEG mRNA in vivo is blocked by MK-801 pretreatment. Northern blots of rat striatal mRNA probed with $c$-fos and jun-B. Rats were treated for $12 \mathrm{~d}$ as summarized in Table 1. Lane 1 represents the control condition; lane 2, the acute amphetamine condition; lane 3, chronic MK-801 condition; lane 4, chronic amphetamine administration (4 mg/ $\mathrm{kg})$; lane 5, chronic amphetamine administration preceded by MK- 801 pretreatment with each dose; and lane 6, chronic amphetamine condition preceded by MK-801 pretreatment for $11 \mathrm{~d}$ with MK- 801 pretreatment replaced by saline on day 12 . Acute treatment with amphetamine $(4 \mathrm{mg} / \mathrm{kg}$ ) leads to a marked induction of IEGs (lane 2); chronic amphetamine administration (lane 4) leads to a reduced response. This downregulation of IEG inducibility is blocked by pretreatment with MK-801 before amphetamine injections, i.e., when MK-801 is omitted at the last injection, the response to amphetamine (lane 6 ) is similar to the acute, indeed greater (lane 2), rather than the chronic (lane 4), amphetamine condition. Rats were killed 30 min after the last injection. Cyclophilin was used as internal loading control; $n=6$.

binding sites. Taken together, the lack of linearity is a mathematical distortion attributable to a difference in the affinity of unlabeled and labeled MK-801 for its binding site, rather than two different binding sites. Interestingly, the conflicting reports about number of binding sites in rodents coincide with the use of these two different methods (Wong et al., 1988; Javitt and Zukin, 1989). Even in the absence of glutamate and glycine, $\left[{ }^{3} \mathrm{H}\right] \mathrm{MK}-801$ binding (using "hot saturation") still was linear, with decreased binding affinity $\left(K_{\mathrm{D}}\right.$ values approximately doubled), but no change in the maximum number of binding sites $\left(B_{\mathrm{MAX}}\right)$. The results are consistent with previously published data in mouse brain (Foster and Wong, 1987; Wong et al., 1988) and suggest that MK-801 interacts solely with the NMDA receptor in the rat strain used in these experiments. Thus, the attenuation of amphetamineinduced gene expression by MK-801 likely is attributable to a blockade of NMDA receptors.

\section{In dissociated striatal neurons, $D_{1}$ dopamine receptor- mediated IEG induction depends on $\mathrm{Ca}^{2+}$ entry via NMDA receptors, but not via L-type $\mathbf{C a}^{2+}$ channels}

To examine whether the observed interaction between NMDA receptors and dopamine receptors occurs only at the level of striatal circuitry or whether significant interactions occur intracellularly within striatal neurons, we turned to dissociated neuronenriched primary striatal cultures in which the natural presynaptic dopamine and glutamate inputs have been removed. Levels of both $c$-fos and jun-B mRNA were examined in nearly all experiments in primary striatal cultures, but because no significant differences were observed in the responsiveness of these two genes, data are shown for $c$-fos mRNA only. As determined by

Table 2. Binding affinities and maximum binding sites for $\left[{ }^{3} \mathrm{H}\right] \mathrm{MK}-801$ in rat striatum, cortex, and hippocampus

\begin{tabular}{llll} 
& Mean & \pm SEM & $N$ (of triplicates) \\
\hline Striatum & & & \\
$\quad K_{\mathrm{D}}$ & $3.3 \mathrm{nM}$ & 0.42 & 2 \\
$B_{\mathrm{MAX}}$ & $1.57 \mathrm{pmol} / \mathrm{mg}$ protein & 0.61 & \\
Cortex & & & \\
$\quad K_{\mathrm{D}}$ & $4.05 \mathrm{nM}$ & 0.58 & 5 \\
$\quad B_{\mathrm{MAX}}$ & $2.35 \mathrm{pmol} / \mathrm{mg}$ protein & 0.66 & \\
Hippocampus & & & \\
$\quad K_{\mathrm{D}}$ & $4.7 \mathrm{nM}$ & 2.55 & 2 \\
$B_{\mathrm{MAX}}$ & $4.13 \mathrm{pmol} / \mathrm{mg}$ protein & 0.18 & \\
\hline
\end{tabular}

Each experiment was done in triplicate.
HPLC analysis on the day of the experiment, glutamate levels in the culture medium range between 1 and $5 \mu \mathrm{M}$, whereas aspartate levels are below detection limit (detection limit was $1 \mu \mathrm{M}$ ).

Dopamine and the $\mathrm{D}_{1}$ agonists SKF 38393 and SKF 82958 all induced $c$-fos in the dissociated cultures (Fig. $4 A, B$ ) consistent with our previous findings (Konradi et al., 1994; Cole et al., 1995). Surprisingly, however, MK-801 $(50 \mu \mathrm{M})$ or the competitive NMDA receptor antagonist APV $(100 \mu \mathrm{M})$ blocked the induction of $c$-fos (Fig. $4 B$ ) and jun-B mRNA (data not shown) by dopamine or the $\mathrm{D}_{1}$ agonists. MK-801 (1 $\left.\mu \mathrm{M}\right)$ also blocked dopaminemediated $c$-fos induction after a $4 \mathrm{hr}$ preincubation (Fig. $4 A$ ) (earlier time points not examined). A prolonged incubation was used with the lower concentration of MK-801, because $\left[{ }^{3} \mathrm{H}\right] \mathrm{MK}$ 801 binding required $4 \mathrm{hr}$ to reach equilibrium in the presence of glutamate and glycine (data not shown). To avoid long exposure to MK-801, we chose a higher, saturating concentration for a short period of time for most of the experiments shown.

NMDA receptor channels are permeable to $\mathrm{Ca}^{2+}$ (MacDermott et al., 1986; Hollmann and Heinemann, 1994). Therefore, we tested the role of $\mathrm{Ca}^{2+}$ in dopamine-mediated $c$-fos (Fig. $5 A, B$ ) expression in the striatal cultures. When cells were grown for $6 \mathrm{hr}$ (data not shown) or $18 \mathrm{hr}$ (Fig. $5 A$ ) in $\mathrm{CaCl}_{2}$-free medium (DMEM/F12 medium normally contains $1 \mathrm{mM} \mathrm{CaCl}_{2}$; DMEM normally contains $1.8 \mathrm{~mm} \mathrm{CaCl}_{2}$ ), the ability of dopamine to induce $c$-fos was markedly reduced. Alternatively, addition of EGTA $(10 \mathrm{~mm})$ to standard medium $6 \mathrm{hr}$ (data not shown) or 18

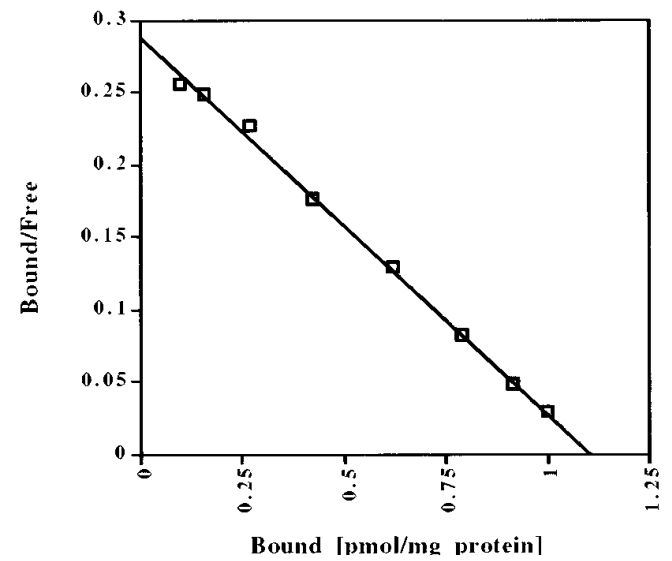

Figure 3. Representative Scatchard plot of $\left[{ }^{3} \mathrm{H}\right] \mathrm{MK}-801$ binding in rat striatum. A "hot saturation" experiment is shown. See Table 2 for all $K_{\mathrm{D}}$ and $B_{\mathrm{MAX}}$ values. 

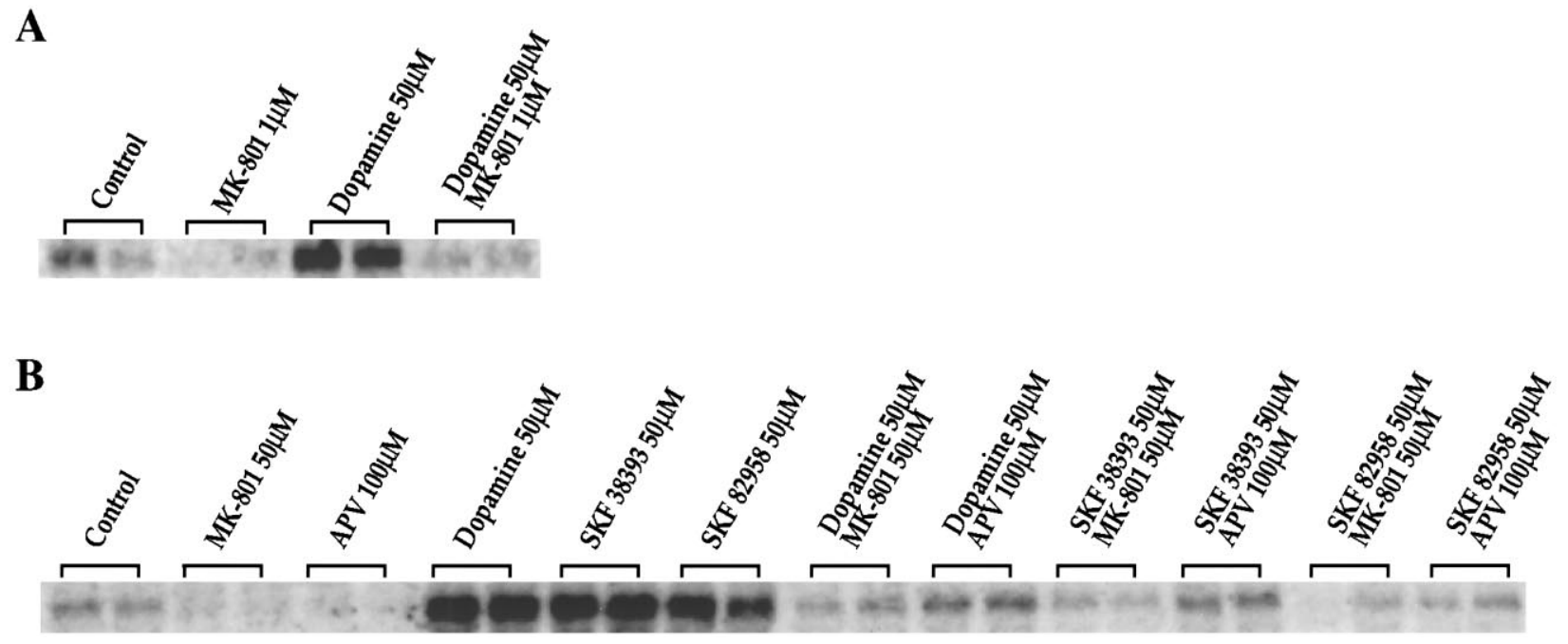

Figure 4. $A, B$, NMDA receptor antagonists inhibit dopamine-induced IEG expression in rat primary striatal cultures. Northern blots from rat primary striatal culture probed with $c$-fos. $A$, Cultures were treated for 30 min with dopamine $(50 \mu \mathrm{M})$. Pretreatment for $4 \mathrm{hr}$ with MK-801 (1 $\mu \mathrm{M})$ blocked $c$-fos induction; $n=4$. $B$, Cultures were treated for 30 min with either dopamine (50 $\mu \mathrm{M})$, SKF $38393(50 \mu \mathrm{M})$, or SKF $82958(50 \mu \mathrm{M})$. Pretreatment for 30 min with MK-801 $(50 \mu \mathrm{M})$ or APV $(100 \mu \mathrm{M})$ prevented $c$-fos induction; $n=8$.

hr (Fig. $5 B$ ) before the addition of dopamine markedly inhibited the induction of $c$-fos (Fig. $5 B$ ) after dopamine stimulation.

Because $\mathrm{D}_{1}$ receptor-mediated activation of protein kinase $\mathrm{A}$ (PKA) enhances the activity of L-type voltage-sensitive $\mathrm{Ca}^{2+}$ channels in striatum (Surmeier et al., 1995), we tested the effects of the L-type $\mathrm{Ca}^{2+}$ channel blockers nifedipine (20 nM to $100 \mu \mathrm{M}$ ) and verapamil (20 nM to $100 \mu \mathrm{M}$ ) on dopamine-mediated IEG induction (Fig. 6; the effects of L-type channel blockers at $100 \mathrm{~nm}$ and $500 \mathrm{~nm}$ are shown). Neither drug inhibited dopaminemediated $c$-fos induction; indeed at higher concentrations $(\mu \mathrm{M}$ range) (data not shown) verapamil increased the induction of $c$-fos. Treatment with depolarizing concentrations of $\mathrm{KCl}$ induced $c$-fos expression (Fig. 7); this induction also was blocked by MK-801 (Fig. 7).

Acting via $D_{1}$ receptors, dopamine causes robust increases in cyclic AMP levels in this primary dissociated striatal culture system (Cole et al., 1995). Therefore, we examined the possibility that the NMDA receptor antagonists were exerting their inhibitory effects on IEG induction by altering cyclic AMP levels. Dopamine and dopamine agonists markedly induced cyclic AMP generation $10 \mathrm{~min}$ after stimulation by the cultures. MK-801 did not affect dopamine agonist-mediated induction of cyclic AMP (Fig. 8).

We have shown previously that dopamine receptor-mediated $c$-fos induction in striatal neurons is dependent on the constitutively expressed transcription factor CREB (Konradi et al., 1994), which interacts with the $c$-fos gene at its CaRE site (Sheng et al., 1990 ) and is activated by phosphorylation of $\operatorname{Ser}^{133}$ (Gonzalez and Montminy, 1989). To investigate further the interaction between dopamine and NMDA receptor pathways, we therefore examined the effects of MK-801 and APV on dopamine-mediated CREB phosphorylation in striatal neurons (Fig. 9). In gel-mobility shift assays using the $c$-fos $\mathrm{CaRE}$ site as a probe (Fig. 9) and a palindromic CREB binding site (ATF) for comparison (which gave identical results to the CaRE probe) (data not shown), we observed no quantitative difference in total CREB binding following dopamine or NMDA receptor antagonists. An antiserum raised against total CREB protein produced a complete supershift in all lanes (data not shown) (see also Konradi et al., 1995). When we examined phosphorylation of CREB, using a specific antiserum directed against $\operatorname{Ser}^{133}$ phosphoCREB (Ginty et al., 1993) for supershifts, we found significant effects of dopamine, which induced a fourfold increase $(n=4)$ in the specific phosphoCREB band. Treatment of cultures with MK-801 (50 $\mu \mathrm{M})$ or APV (100 $\mu \mathrm{M})$ in the absence of dopamine decreased $\operatorname{Ser}^{133}$ phosphoCREB below basal levels (Fig. 9, right). Both of the NMDA receptor antagonists blocked dopamine-induced CREB phosphorylation, i.e., CREB phosphorylation remained at basal levels (Fig. 9; right).

A

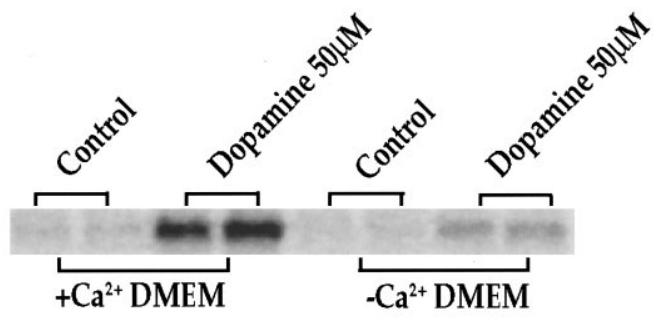

B

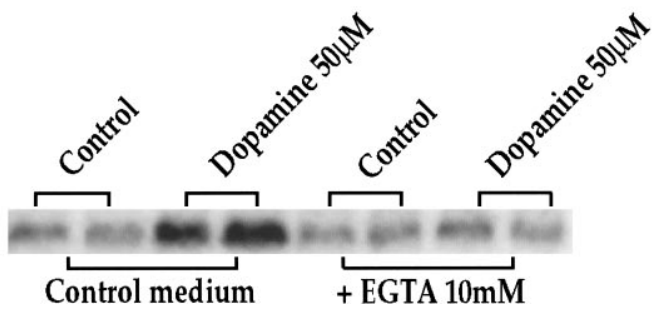

Figure 5. $A, \mathrm{Ca}^{2+}$-poor medium reduces dopamine-induced IEG expression significantly. Northern blots from rat primary striatal culture probed with $c$-fos. Cultures were treated for 30 min with dopamine $(50 \mu \mathrm{M})$ in regular medium $\left(+\mathrm{Ca}^{2+}\right.$ DMEM) or $\mathrm{CaCl}_{2}$-free medium $\left(-\mathrm{Ca}^{2+}\right.$ DMEM). Experiments were performed 6 (data not shown) and $18 \mathrm{hr}$ after media change; $n=4$. $B$, EGTA reduces dopamine-mediated IEG induction significantly. Northern blots from rat primary striatal culture probed with $c$-fos. Cultures were treated for 30 min with dopamine $(50 \mu \mathrm{M})$ in control medium or in the presence of $10 \mathrm{~mm}$ EGTA. Experiments were performed 6 (data not shown) and $18 \mathrm{hr}$ after addition of EGTA; $n=4$. 


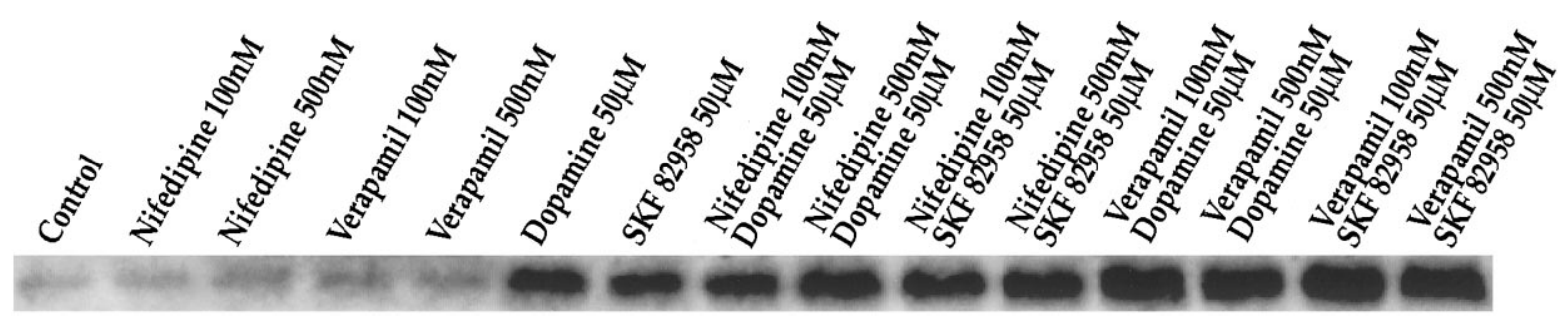

Figure 6. L-type $\mathrm{Ca}^{2+}$ channel blockers do not inhibit dopamine-induced c-fos induction in primary striatal cultures. Northern blots from rat primary striatal culture probed with $c$-fos. The L-type $\mathrm{Ca}^{2+}$ channel blockers nifedipine and verapamil (concentrations shown for both inhibitors, 100 and $500 \mathrm{nM}$ ) do not block dopamine- or SKF 82958-induced $c$-fos expression; $n=4$.

$\mathrm{KCl}$ treatment also induced CREB phosphorylation (twofold increase as demonstrated by a supershift with the phosphoCREB antiserum), which was blocked by MK-801 (Fig. 10).

To examine whether $\mathrm{Ca}^{2+}$ and NMDA receptor dependence is a general mechanism for cyclic AMP pathways of which the D1 pathway is an example, we examined the effect of NMDA receptor antagonists on forskolin-mediated IEG expression. Forskolin, which stimulates adenylyl cyclase directly, bypasses the $\mathrm{D}_{1}$ dopamine receptor and is a strong activator of $c$-fos in primary striatal cultures (Konradi et al., 1994). Surprisingly, we found that forskolin-induced IEG expression also is inhibited by MK-801 and APV (Fig. 11) in the cultures.

\section{DISCUSSION}

The transient induction of IEG transcription factors in striatal neurons is a well-studied cellular response to amphetamine and cocaine administration (Graybiel et al., 1990; Young et al., 1991; Hope et al., 1992; Nguyen et al., 1992; Konradi et al., 1994; Kosofsky et al., 1995). As a cellular marker, the induction of IEGs has been used to map neurons and circuits activated by amphetamine and cocaine. Moreover, it has been proposed that IEGs might couple some of the acute actions of these drugs to longterm alterations in neural function. Dopamine receptor-mediated IEG induction has been shown to exhibit some properties of tolerance with chronic administration (Hope et al., 1992), thus paralleling results of behavioral studies (De Montis et al., 1992).

Based on the ability of the $\mathrm{D}_{1}$ dopamine receptor antagonist SCH23390 to block amphetamine-induced striatal IEG expression in vivo (Graybiel et al., 1990; Nguyen et al., 1992) and dopamineinduced IEG expression in striatal cultures (Konradi et al., 1994), it has been argued that $D_{1}$ receptor-mediated activation of the cyclic AMP pathway is a critical mechanism of IEG induction. Evidence that the NMDA receptor antagonist MK-801 (Ohno et al., 1994; Wang et al., 1994) also blocks amphetamine-induced

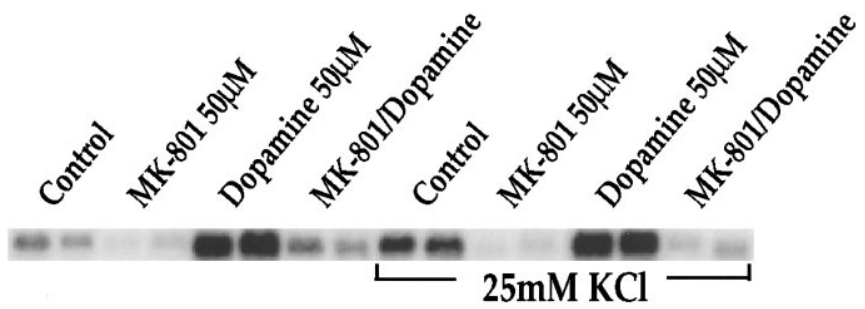

Figure 7. KCl-mediated $c$-fos induction is inhibited by MK-801. Northern blots from rat primary striatal culture probed for $c$-fos mRNA. MK-801 $(50 \mu \mathrm{M})$ inhibited dopamine-mediated $(50 \mu \mathrm{M}) c$-fos induction in the presence and absence of $\mathrm{KCl}(25 \mathrm{mM})$ as well as $c$-fos induced by $\mathrm{KCl}$ alone (compare lanes control and $M K-801$ in the presence of $\mathrm{KCl}$ to control lane without $\mathrm{KCl}$ ). All treatments in duplicate; $n=6$.
IEG induction in vivo does not provide information as to whether the substrate of the dopamine/glutamate interaction is at the level of striatal circuits or at the level of intracellular signaling within individual striatal neurons.

In this report, we characterized further the effects of MK-801 on amphetamine-induced IEG expression in vivo. Most notably, we find that MK-801 pretreatment before daily doses of amphetamine blocks the downregulation of IEG induction that has been proposed as a model of biochemical tolerance. Indeed, with daily MK-801 pretreatment, the striatum is, if anything, hyperresponsive to amphetamine. MK-801 previously has been shown to block behavioral responses to cocaine or amphetamine including sensitization (Itzhak and Stein, 1992; Wolf and Jeziorski, 1993; Hoffman, 1994; Ohno et al., 1994) or reverse tolerance (Karler et al., 1989) and tolerance (De Montis et al., 1992). The present data provide a molecular correlate of the ability of MK-801 to inhibit an effect of chronic amphetamine administration. This finding may provide clues to the cellular mechanisms by which NMDA receptor antagonists may block long-term behavioral effects of psychostimulants.

Because most of the in vivo data, including our own, have been obtained with MK-801, we investigated the possibility that MK801 exerts its action via receptors other than the NMDA receptor. In multiple rat brain areas and under different binding conditions,

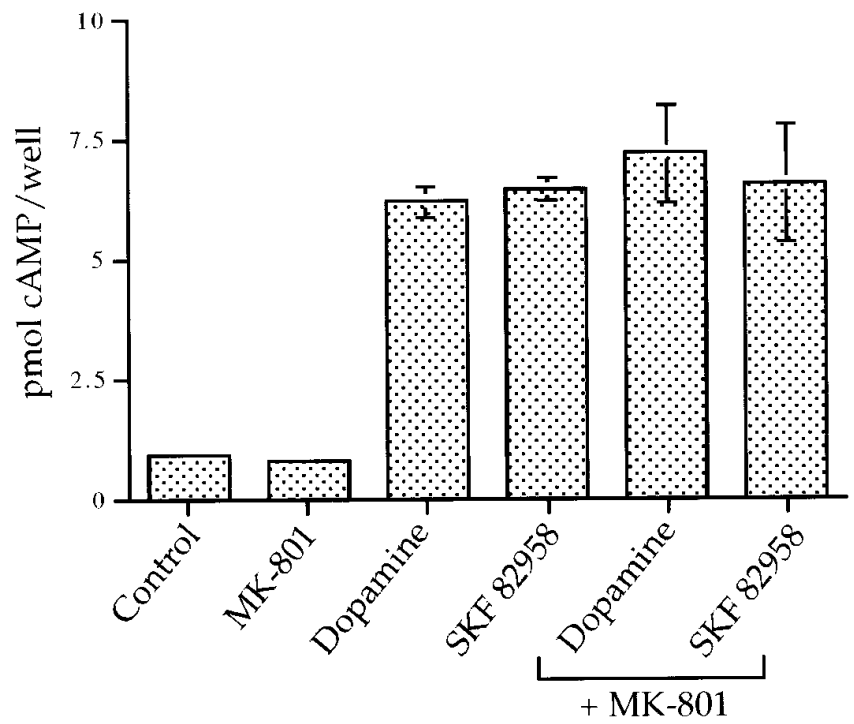

Figure 8. The NMDA receptor antagonist MK-801 does not affect dopamine-induced cyclic AMP levels in primary striatal cultures. MK-801 $(50 \mu \mathrm{M})$ does not affect dopamine- $(50 \mu \mathrm{M})$ or SKF 82958- $(50 \mu \mathrm{M})$ induced cyclic AMP levels 10 min after stimulation; $n=3$. 


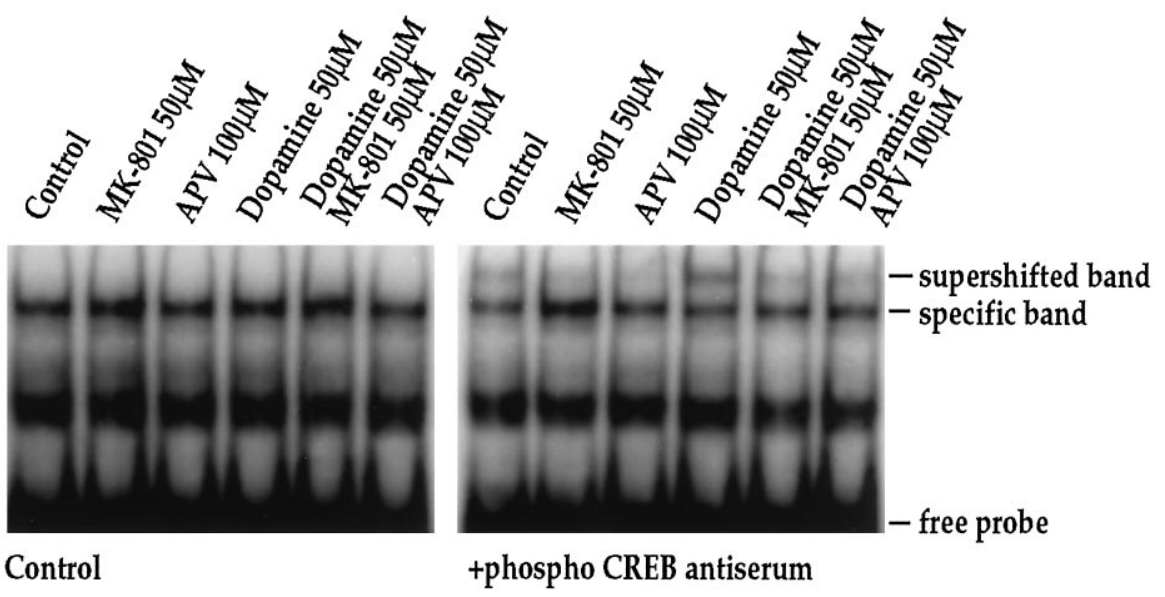

Figure 9. Dopamine-induced CREB phosphorylation is blocked by NMDA receptor antagonists. In the absence of phosphoCREB antiserum, no quantitative difference in CREB binding to the CaRE or palindromic CREB/ATF (data not shown) site is observed. The phosphoCREB antiserum interacts with part of the bound complex (supershifted band) in experiments performed 15 min after stimulation with dopamine $(50 \mu \mathrm{M})$. Pretreatment of cultures for 30 min with MK-801 $(50 \mu \mathrm{M})$ or APV $(100 \mu \mathrm{M})$ prevents phosphorylation of CREB, as demonstrated by the lack of a supershifted band in the respective lanes; $n=4$. only a single, high-affinity MK-801 binding site was observed in the strain of rats used in our experiments. Moreover, in primary striatal cultures, the effects of MK-801 were not significantly different than the effects of APV, an unrelated competitive NMDA receptor antagonist.

Studies in intact animals cannot address the question of whether NMDA/D $\mathrm{D}_{1}$ dopamine receptor interactions depend on circuitry or intraneuronal interactions. Indeed, it has been demonstrated that glutamate receptors including NMDA receptors on presynaptic dopamine terminals can modulate dopamine release (Kashihara et al., 1990; Johnson and Jeng, 1991; Krebs et al., 1991; Wang, 1991). To distinguish a potential postsynaptic-intracellular interaction from such a presynaptic-intercellular mechanism, we used dissociated primary striatal cultures, a preparation that removes presynaptic terminals. In these cultures, we supplied glutamate and dopamine in the media, glutamate continuously, and dopamine at discrete times to model the phasic stimulation produced by amphetamine. We found that even in dissociated cultures, blockade of NMDA receptors by MK-801 or APV substantially inhibited the ability of dopamine to induce IEGs. Thus, there is an intracellular substrate that may account for a significant component of the glutamate/dopamine interaction observed in vivo.

To elucidate further the requirement for NMDA receptors in dopamine-mediated IEG expression, we investigated the role of $\mathrm{Ca}^{2+}$ entry and found that extracellular $\mathrm{Ca}^{2+}$ was required. Complex interactions between the cyclic AMP pathway and L-, N-, and P-type $\mathrm{Ca}^{2+}$ channels have been documented within acutely dissociated adult striatal neurons (Surmeier et al., 1995). In particular, $\mathrm{D}_{1}$ stimulation has been shown to activate L-type $\mathrm{Ca}^{2+}$ channels (Surmeier et al., 1995), yielding a potential mechanism of interaction between $\mathrm{D}_{1}$ receptors and $\mathrm{Ca}^{2+}$ in regulating gene expression. However, L-type $\mathrm{Ca}^{2+}$ channel blockers did not inhibit dopamine-induced IEG expression. Previous studies have demonstrated that in hippocampal neurons, different modes of $\mathrm{Ca}^{2+}$ entry can activate $c$-fos expression via different intracellular pathways (Lerea et al., 1992; Bading et al., 1993; Lerea and McNamara, 1993). We find that in striatal cultures, both cyclic AMP-mediated IEG expression and $\mathrm{KCl}$ depolarization-mediated IEG expression require active NMDA receptors.

There was a strong correlation between the effects of NMDA receptor blockers on $c$-fos mRNA and on phosphorylation of $\mathrm{CREB}$, consistent with our previous findings that amphetamineinduced $c$-fos expression in the striatum is dependent on transcription factor CREB (Konradi et al., 1994). However, these experi- ments do not rule out roles for other signaling pathways or transcription factors in cyclic AMP or $\mathrm{Ca}^{2+}$-regulated gene expression (Runkel et al., 1991; Robertson et al., 1995), especially for genes other than $c$-fos. It is noteworthy that induction of $c$-jun, which lacks a consensus serum response element (SRE) or CRE (Hattori et al., 1988), was inhibited by NMDA receptor antagonists in vivo.

Bading et al. (1993) had found, using transfected $c$-fos promoter constructs, that in hippocampal neurons the SRE was primarily responsible for induction of $c$-fos gene expression by the NMDA receptor pathway, whereas the CaRE element mediated $c$-fos gene expression via L-type $\mathrm{Ca}^{2+}$ channels. In those studies, NMDA receptor activation by itself was inadequate to stimulate transcription from a single CRE (the $c$-fos CaRE element), although a possible role for CREs in NMDA receptor-mediated $c$-fos gene expression was not ruled out. The experiments described here do not rule out some role for the $c$-fos SRE in $\mathrm{D}_{1}$-mediated regulation. Other evidence, which supports a role for CREs in dopamine-mediated gene expression, is that in the same striatal culture system used for the present studies, dopamine-regulated prodynorphin gene expression has been

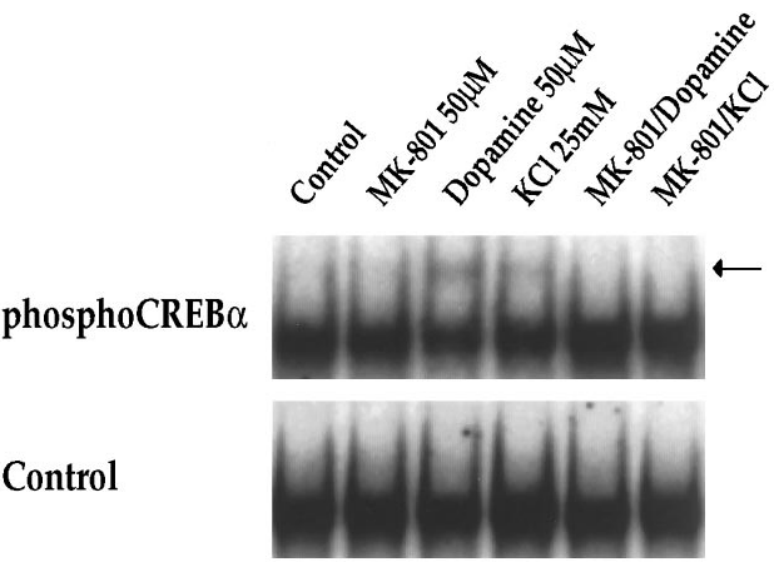

Figure 10. KCl-induced CREB phosphorylation is blocked by MK-801. In the absence of phosphoCREB antiserum, no quantitative difference in CREB binding to the CaRE site is observed (Control). The phosphoCREB antiserum interacts with part of the bound complex (creating the supershifted band, see arrow) in experiments performed 15 min after stimulation with dopamine $(50 \mu \mathrm{M})$ or $\mathrm{KCl}(25 \mathrm{~mm})$. Pretreatment of cultures for $30 \mathrm{~min}$ with MK-801 $(50 \mu \mathrm{M})$ prevents phosphorylation of CREB in both paradigms, as demonstrated by the lack of a supershifted band in the respective lanes; $n=6$. 


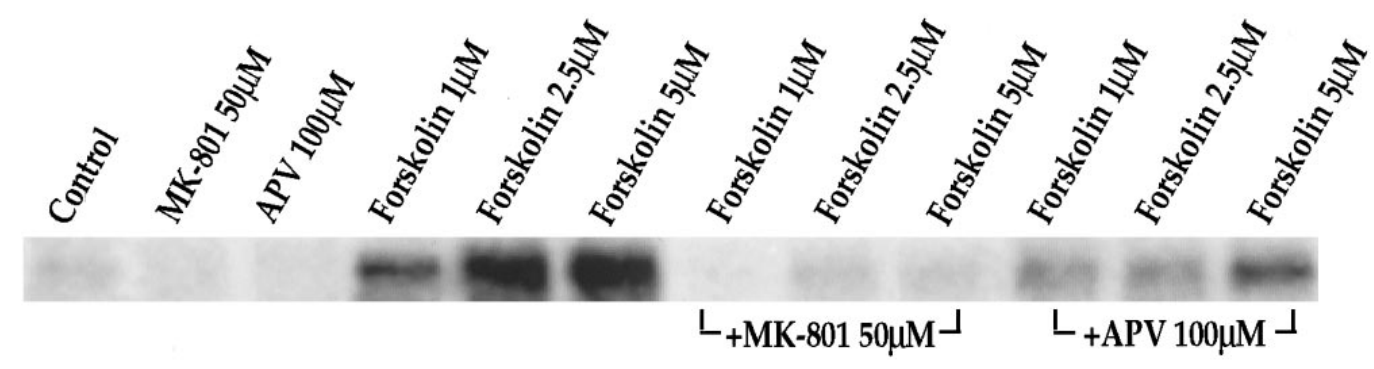

Figure 11. Forskolin-mediated c-fos expression is inhibited by NMDA receptor antagonists. Northern blots from rat primary striatal cultures probed with $c$-fos. Cultures were treated for 30 min with forskolin $(1-5 \mu \mathrm{M})$. Pretreatment for 30 min with MK-801 (50 $\mu \mathrm{M})$ or APV (100 $\mu \mathrm{M})$ inhibited $c$-fos induction. Increasing forskolin concentrations were able to partially overcome the block of $c$-fos induction exerted by the competitive NMDA antagonist APV; $n=4$.

mapped previously to three CREs that interact with CREB (Cole et al., 1995). The dopamine-inducible prodynorphin constructs did not contain an SRE-like element or a functional AP-1 element (Douglass et al., 1994; Cole et al., 1995). In comparing our findings with those of Bading et al. (1993), it must be noted that both the cell type and the activated signaling pathways differ, i.e., in our striatal culture paradigm, the cAMP pathway was activated in association with the NMDA receptor pathway; in the previous studies of hippocampal neurons, the cAMP pathway was not activated.

We conclude that $\mathrm{D}_{1}$ dopamine receptor-mediated IEG expression in striatal neurons requires functional NMDA receptors and $\mathrm{Ca}^{2+}$. These findings do not rule out significant circuit-based interactions between dopamine and NMDA receptors in vivo. Additional studies are needed to address the level at which the dopamine/cyclic AMP and NMDA receptor pathways interact within cells. Mechanisms deserving additional investigation include cyclic AMP/PKA-stimulated phosphorylation of NMDA receptors, which might alter $\mathrm{Ca}^{2+}$ influx (see also Chen and Huang, 1992; Cepeda et al., 1993) as well as interactions at the level of protein kinases and transcription factors. It has become clear that $\mathrm{D}_{1}$ dopamine receptor-mediated regulation of striatal gene expression is far more complex than it first appeared, even for well-characterized genes such as $c$-fos.

\section{REFERENCES}

Amador M, Dani JA (1991) MK-801 inhibition of nicotinic acetylcholine receptor channels. Synapse 7:207-215.

Bading H, Ginty DD, Greenberg ME (1993) Regulation of gene expression in hippocampal neurons by distinct calcium signaling pathways. Science 260:181-186.

Berger SL, Chirgwin JM (1989) Isolation of RNA. Methods Enzymol 180:3-13.

Bradford MM (1976) A rapid and sensitive method for the quantitation of microgram quantities of protein utilizing the principle of protein-dye binding. Anal Biochem 72:248-254.

Butcher SP, Fairbrother IS, Kelly JS, Arbuthnott GW (1988) Amphetamine-induced dopamine release in the rat striatum: an in vivo microdialysis study. J Neurochem 50:346-355.

Cepeda C, Buchwald NA, Levine MS (1993) Neuromodulatory actions of dopamine in the neostriatum are dependent upon the excitatory amino acid receptor subtypes activated. Proc Natl Acad Sci USA 90:9576-9580.

Chen L, Huang LYM (1992) Protein kinase C reduces $\mathrm{Mg}^{2+}$ block of NMDA receptor channels as a mechanism of modulation. Nature 356:521-523.

Cole RL, Konradi C, Douglass J, Hyman SE (1995) Neuronal adaptation to amphetamine and dopamine: molecular mechanisms of prodynorphin gene regulation in rat striatum. Neuron 14:813-823.

Danielson PE, Forss-Petter S, Brow MA, Calavetta L, Douglass J, Milner RJ, Sutcliffe JG (1988) p1B15: a cDNA clone of the rat mRNA encoding cyclophilin. DNA 7:261-267.
Dash PK, Karl KA, Colicos MA, Prywes R, Kandel ER (1991) cAMP response element-binding protein is activated by $\mathrm{Ca}^{2+} /$ calmodulin-as well as cAMP-dependent protein kinase. Proc Natl Acad Sci USA 88:5061-5065.

De Montis MG, Devoto P, Meloni D, Gambarana C, Giorgi G, Tagliamonte A (1992) NMDA receptor inhibition prevents tolerance to cocaine. Pharmacol Biochem Behav 42:179-182.

Douglass J, McKinzie AA, Pollock KM (1994) Identification of multiple DNA elements regulating basal and protein kinase A-induced transcriptional expression of the rat prodynorphin gene. Mol Endocrinol 8:333-344.

Dragunow M, Faull RL (1990) MK801 induces c-fos protein in thalamic and neocortical neurons of rat brain. Neuroscience Lett 113:144-150.

Feinberg AP, Vogelstein B (1983) A technique for radiolabeling DNA restriction endonuclease fragments to high specific activity. Anal Biochem 132:6-13.

Foster AC, Wong EHF (1987) The novel anticonvulsant MK-801 binds to the activated state of the $N$-methyl-D-aspartate receptor in rat brain. Br J Pharmacol 91:403-409.

Ginty DD, Kornhauser JM, Thompson MA, Bading H, Mayo KE, Takahashi JS, Greenberg ME (1993) Regulation of CREB phosphorylation in the suprachiasmatic nucleus by light and circadian clock. Science 260:238-241.

Gonzalez GA, Montminy MR (1989) Cyclic AMP stimulates somatostatin gene transcription by phosphorylation of CREB at serine 133. Cell 59:675-680.

Graybiel AM, Moratalla R, Robertson HA (1990) Amphetamine and cocaine induce drug specific activation of the c-fos gene in striosomematrix compartments and limbic subdivisions of the striatum. Proc Natl Acad Sci USA 87:6912-6916.

Hattori K, Angel P, LeBeau MM, Karin M (1988) Structure and chromosomal location of the functional intronless human JUN protooncogene. Proc Natl Acad Sci USA 85:9148-9152.

Hoeffler JP, Meyer TE, Yun Y, Jameson JL, Habener JF (1988) Cyclic AMP-responsive DNA-binding protein: structure based on a cloned placental DNA. Science 242:1430-1433.

Hoffman DC (1994) The noncompetitive NMDA antagonist MK-801 fails to block amphetamine-induced place conditioning in rats. Pharmacol Biochem Behav 47:907-912.

Hollmann M, Heinemann S (1994) Cloned glutamate receptors. Ann Rev Neurosci 17:31-108.

Hope B, Kosofsky B, Hyman SE, Nestler EJ (1992) Regulation of immediate early gene expression and AP-1 binding in the rat nucleus accumbens by chronic cocaine. Proc Natl Acad Sci USA 89:5764-5768.

Itzhak Y, Stein I (1992) Sensitization to the toxic effects of cocaine in mice is associated with the regulation of $N$-methyl-D-aspartate receptors in the cortex. J Pharmacol Exp Ther 262:464-470.

Javitt DC, Zukin SR (1989) Interaction of $\left[{ }^{3} \mathrm{H}\right] \mathrm{MK}-801$ with multiple states of the $N$-methyl-D-aspartate receptor complex of rat brain. Proc Natl Acad Sci USA 86:740-744.

Johnson KM, Jeng Y-J (1991) Pharmacological evidence for $N$-methyl$\mathrm{D}$-aspartate receptors on nigrostriatal dopaminergic nerve terminals. Can J Physiol Pharmacol 69:1416-1421.

Karler R, Calder LD, Chaudhry IA, Turkanis SA (1989) Blockade of "reverse tolerance" to cocaine and amphetamine by MK-801. Life Sci 45:599-606. 
Kashihara K, Hamamura T, Okumura K, Otsuki S (1990) Effect of MK801 on endogenous dopamine release in vivo. Brain Res 528:80-82.

Kavanaugh MP, Tester BA, Weber E (1989) Interaction of MK-801 with the nicotinic acetylcholine receptor-associated ion channel from electroplax. Eur J Pharmacol 164:397-398.

Kebabian JW, Calne DB (1979) Multiple receptors for dopamine. Nature 277:93-96.

Klawans HL, Margolin DI, Dava N, Crosset P (1978) Supersensitivity to D-amphetamine and apomorphine-induced stereotyped behavior induced by chronic D-amphetamine administration. J Neurol Sci 25:283-289.

Konradi C, Cole RL, Heckers S, Hyman SE (1994) Amphetamine regulates gene expression in rat striatum via transcription factor CREB. J Neurosci 14:5623-5634.

Konradi C, Cole RL, Green D, Senatus P, Leveque J-C, Pollack A, Grossbard SJ, Hyman SE (1995) Analysis of the proenkephalin second messengerinducible enhancer in rat striatal cultures. J Neurochem 65:1007-1015.

Kornhuber J, Mack-Burkhardt F, Kornhuber ME, Riederer P (1989) $\left[{ }^{3} \mathrm{H}\right] \mathrm{MK}-801$ binding sites in post-mortem human frontal cortex. Eur J Pharmacol 162:483-490.

Kosofsky BE, Genova LM, Hyman SE (1995) Substance P phenotype defines specificity of c-fos induction by cocaine in developing rat striatum. J Comp Neurol 351:41-50.

Krebs MO, Desce JM, Kemel ML, Gauchy C, Godeheu G, Cheramy A, Glowinski J (1991) Glutamatergic control of dopamine release in the rat striatum: evidence for presynaptic $N$-methyl-D-aspartate receptors on dopaminergic nerve terminals. J Neurochem 56:81-85.

Lerea LS, McNamara JO (1993) Ionotropic glutamate receptor subtypes activate c-fos transcription by distinct calcium-requiring intracellular signaling pathways. Neuron 10:31-41.

Lerea LS, Butler LS, McNamara JO (1992) NMDA and non-NMDA receptor-mediated increase of c-fos mRNA in dentate gyrus neurons involves calcium influx via different routes. J Neurosci 12:2973-2981.

MacDermott AB, Mayer ML, Westbrook GL, Smith SJ, Barker JL (1986) NMDA-receptor activation increases cytoplasmic calcium concentration in cultured spinal cord neurones. Nature 321:519-522.

McMillan BA (1983) CNS stimulants: two distinct mechanisms of action for amphetamine-like drugs. Trends Pharmacol Sci 4:429-432.

Monsma FJ, Mahan LC, Vittie LD, Gerfen CR, Sibley DR (1990) Molecular cloning and expression of a $\mathrm{D}_{1}$ dopamine receptor linked to adenylyl cyclase activation. Proc Natl Acad Sci USA 87:6723-6727.

Montminy MR, Bilezikjian LM (1987) Binding of a nuclear protein to the cyclic-AMP response element of the somatostatin gene. Nature 328:175-178.

Moore KE (1977) The actions of amphetamine on neurotransmitters: a brief review. Biol Psychol 12:451-462.

Moratalla R, Robertson HA, Graybiel AM (1992) Dynamic regulation of NGFI-A (zif 268, egr1) gene expression in the striatum. J Neurosci 12:2609-2622.

Munson PJ, Rodbard D (1980) Ligand: a versatile computerized approach for characterization of ligand-binding systems. Anal Biochem 107:220-239.

Nguyen TV, Kobierski L, Comb M, Hyman SE (1990) The effect of depolarization on expression of the human proenkephalin gene is synergistic with cAMP and dependent upon a cAMP-inducible enhancer. J Neurosci 10:2825-2833.

Nguyen TV, Kosofsky B, Birnbaum R, Cohen BM, Hyman SE (1992) Differential expression of c-fos and zif 268 in rat striatum after haloperidol, clozapine and amphetamine. Proc Natl Acad Sci USA 89:4270-4274.

Ohno M, Yoshida H, Watanabe S (1994) NMDA receptor-mediated expression of Fos protein in the rat striatum following methamphetamine administration: relation to behavioral sensitization. Brain Res 665:135-140.
Olney JW, Labruyere J, Price MT (1989) Pathological changes induced in cerebrocortical neurons by phencyclidine and related drugs. Science 244:1360-1362.

Robertson LM, Kerppola TK, Vendrell M, Luk D, Smeyne RJ, Bocchiaro C, Morgan JI, Curran T (1995) Regulation of c-fos expression in transgenic mice requires multiple interdependent transcription control elements. Neuron 14:241-252.

Robinson TE, Becker JB (1986) Enduring changes in brain and behavior produced by chronic amphetamine administration: a review and evaluation of animal models of amphetamine psychosis. Brain Res 396:157-198.

Runkel L, Shaw PE, Herrera RE, Hipskind RA, Nordheim A (1991) Multiple basal promotor elements determine the level of human $c$-fos transcription. Mol Cel Biol 11:1270-1280.

Sambrook J, Fritsch EF, Maniatis T (1989) Molecular cloning, 2nd Ed. Cold Spring Harbor, NY: Cold Spring Harbor Laboratory.

Sassone-Corsi P, Sisson JC, Verma IM (1988a) Transcriptional autoregulation of the proto-oncogene fos. Nature 334:314-319.

Sassone-Corsi P, Visvader J, Ferland L, Mellon PL, Verma IM (1988b) Induction of proto-oncogene fos transcription through the adenylate cyclase pathway: characterization of a cAMP-responsive element. Genes Dev 2:1529-1538.

Segal DS, Weinberger SB, Cahill T, McCunney SJ (1980) Multiple daily amphetamine administration: behavioral and neurochemical alterations. Science 207:904-906.

Sheng M, McFadden G, Greenberg ME (1990) Membrane depolarization and calcium induce $c$-fos transcription via phosphorylation of transcription factor CREB. Neuron 4:571-582.

Sheng M, Thompson MA, Greenberg ME (1991) CREB: a Ca(2+)regulated transcription factor phosphorylated by calmodulin-dependent kinases. Science 252:1427-1430.

Snyder-Keller AM (1991) Striatal c-fos induction by drugs and stress in neonatally dopamine-depleted rats given nigral transplants: importance of NMDA activation and relevance to sensitization phenomena. Exp Neurol 113:155-165.

Sun P, Enslen H, Myung PS, Maurer RA (1994) Differential activation of CREB by $\mathrm{Ca}^{2+} /$ calmodulin-dependent protein kinases type II and type IV involves phosphorylation of a site that negatively regulates activity. Genes Dev 8:2527-2539.

Surmeier DJ, Bargas J, Hemmings Jr HC, Nairn AC, Greengard P (1995) Modulation of calcium currents by a D1 dopaminergic protein kinase/ phosphatase cascade in rat neostriatal neurons. Neuron 14:385-397.

Torres G, Rivier C (1993) Cocaine-induced expression of striatal c-fos in the rat is inhibited by NMDA receptor antagonists. Brain Res Bull 30:173-176.

Wang JQ, Daunais JB, McGinty JF (1994) NMDA receptors mediate amphetamine-induced upregulation of zif/268 and preprodynorphin mRNA expression in rat striatum. Synapse 18:343-353.

Wang KT (1991) Presynaptic glutamate receptors modulate dopamine release from striatal synaptosomes. J Neurochem 57:819-822.

Wolf ME, Jeziorski M (1993) Coadministration of MK-801 with amphetamine, cocaine or morphine prevents rather than transiently masks the development of behavioral sensitization. Brain Res 613:291-294.

Wong EHF, Kemp JA, Priestley T, Knight AR, Woodruff GN, Iversen LL (1986) The anticonvulsant MK- 801 is a potent $N$-methyl-D-aspartate antagonist. Proc Natl Adad Sci USA 83:7104-7108.

Wong EHF, Knight AR, Woodruff GN (1988) [ $\left.{ }^{3} \mathrm{H}\right] \mathrm{MK}-801$ labels a site on the $N$-methyl-D-aspartate receptor channel complex in rat brain membranes. J Neurochem 50:274-281.

Young ST, Porrino LJ, Iadarola MJ (1991) Cocaine induces striatal c-fos-immunoreactive proteins via dopaminergic D1 receptors. Proc Natl Acad Sci USA 88:1291-1295. 